\title{
A COMPARATIVE STUDY OF FREE CONJUNCTIVAL AUTOGRAFT VERSUS CONJUNCTIVAL AUTOGRAFT WITH STEM CELL TRANSFER IN PRIMARY PTERYGIUM
}

K. Satish1, D.N. Prakash², Meghana Tanwar³, Madhumita Gopal4, Savita Patil5, Ambika A Acharya ${ }^{6}$, Amar Kulkarni ${ }^{7}$, Mohan Setlur ${ }^{8}$

HOW TO CITE THIS ARTICLE:

K Satish, DN Prakash, Meghana Tanwar, Madhumita Gopal, Savita Patil, Ambika A Acharya, Amar Kulkarni, Mohan Setlur. "A comparative study of free conjunctival autograft versus conjunctival autograft with stem cell transfer in primary pterygium". Journal of Evolution of Medical and Dental Sciences 2013; Vol. 2, Issue 45, November 11; Page: 8805-8812.

ABSTRACT: PURPOSE: To study the effectivity of free conjunctival autograft versus autologous stem cell transfer in primary pterygium in terms of change in astigmatism, recurrence rate and cosmetic appearance. METHODS: The study was conducted at K.R.HOSPITAL from Jan 2012 to June 2012. 100 patients were selected of which 50 patients between age group of 26-58 years underwent pterygium excision with free conjunctival autograft surgery and the remaining age matched group underwent pterygium excision with autologous stem cell transfer. The patients were followed up for a period of 6months. RESULTS: The results were tabulated and analyzed in terms of change in astigmatism and recurrence rate. CONCLUSION: The results showed that free conjunctival autografts were equally effective when compared to autologous stem cell transfer in primary pterygium.

KEYWORDS: Pterygium, autografting, free conjunctival autograft, limbal stem cell graft.

INTRODUCTION: Pterygium is a triangular fibrovascular subepithelial ingrowth of degenerative bulbar conjunctival tissue over the limbus onto the cornea1.

The first described surgical removal of a pterygium was by Susruta ${ }^{2}$. Since then, a considerable number of surgical techniques have been described for its management: simple resection or bare sclera technique, ${ }^{3,4}$ avulsion, ${ }^{5}$ removal and primary closure, $3,6,7$ pterygium head transplant,8-10 concomitant beta irradiation ${ }^{13}$, conjunctival autograft 15,19 , limbal conjunctival autograft 15-18, and the use of amniotic membrane with and without conjunctival grafts 20 . Also attempted are adjunctive therapies aiming at suppressing regrowth of subconjunctival tissue, such as - beta irradiation, thiotepa, and topical postoperative mitomycin $\mathrm{C}^{21,22}$; these are associated with complications such as disfiguring skin depigmentation, cataract formation, severe secondary glaucoma, uveitis, corneal perforation, and scleral necrosis, resulting in perforation and endophthalmitis 11-13. Thus, compared with other techniques, conjunctival autografting after pterygium excision is associated with lower rates of recurrence and complications.

In 1985, Kenyon et al 19 described their procedure of conjunctival autograft for the management of recurrent or advanced pterygium with a low recurrence rate of 5.3\%. Although more time consuming, this surgical technique was found to be safe and effective in reducing the number of recurrences while avoiding the risk of potentially serious complications ${ }^{23,24}$. Most reports also advocate a thin graft devoid of Tenon's fascia but one which is large enough to completely cover the bare scleral defect ${ }^{19}$. However, studies performed in high-risk populations (people residing in 
tropical countries, working outdoors) observed higher recurrence rates using the same surgical technique 25 .

Once it was established that corneal epithelial stem cells are located at the limbus, it was suggested that healthy limbal epithelium acts as a junctional barrier to conjunctival migration onto the corneal surface 26,27 . Also, pterygium was speculated to represent a "local limbal stem cell deficiency (LSD)" 28. Accordingly, inclusion of limbal epithelium in the conjunctival graft for pterygium surgery would achieve better anatomic and functional reconstruction after pterygium removal and, by restoring barrier function of the limbus, could reduce recurrence. Limbal autograft transplantation has been used successfully for treating chemical, thermal, or contact lens associated corneal injury ${ }^{29}$. The method has been reported to be more effective for establishing a healthy ocular surface than conjunctival transplantation in rabbits ${ }^{30}$. Recent studies have reported the effectiveness of limbal conjunctival autograft transplantation in the prevention of recurrence of pterygia 31,32 .

Recurrence is defined and graded in the following manner: Grade 1 indicates that the appearance of the operated site was not different from the normal appearance. Grade 2 indicates some fine episcleral vessels in the excised area extending up to, but not beyond, the limbus and without any fibrous tissue. Grade 3 indicates additional fibrous tissues in the excised area that did not invade the cornea. Grade 4 represents a true recurrence, with fibrovascular tissue invading the cornea.

\section{AIMS \& OBJECTIVES:}

1. To know the outcome of free conjunctival autograft versus autologous limbal stem cell graft surgery.

2. To study the outcome in terms of cosmetic appear ance and visual acuity.

3. To study the complications in terms of recurrence.

\section{MATERIALS AND METHODS:}

INCLUSION CRITERIA: Patients with primary pterygium with less than $3 \mathrm{~mm}$ encroachment upon the cornea (Grade I \&II).

\section{EXCLUSION CRITERIA:}

1. Primary pterygium with more than $3 \mathrm{~mm}$ encroachment upon the cornea (Grade III).

2. Recurrent pterygium.

3. Pseudo pterygium

4. Preexisting ocular surface and intra ocular diseases were excluded.

The study was conducted at K.R.HOSPITAL from Jan 2012 to June 2012, 100 patients who fulfill the inclusion criteria were selected and they were divided into two groups (Group A \&B). Routine ophthalmic examinations including visual acuity, slit lamp examination, fundus evaluation and keratometric readings were taken in all patients.

Preoperatively $45 \%$ had Astigmatism. Out of which $44.4 \%$ (20 eyes) had WTR astigmatism, $35.6 \%$ (16 eyes) had oblique, 20\% ( 9 eyes) had ATR astigmatism. 
50 patients underwent pterygium excision with free conjunctival auto grafting using 10-0 nylon sutures, 50 patients underwent pterygium excision with conjunctival auto grafting with stem cell transfer using 10-0 nylon sutures.

The operations were performed under peribulbar anesthesia with lidocaine hydrochloride $2 \%$ and $0.5 \%$ bupivacaine. A solid lid speculum was used to expose the surgical field. Superior rectus bridle suture was put to improve exposure. Westcott scissors were used to excise the pterygium from the surrounding conjunctiva. The body of the pterygium was lifted from the conjunctival surface, and the head of the pterygium was then avulsed and the remaining tissue was scraped from the corneal surface with a No 15 blade. Any episcleral scarring was removed.

At this stage, using a random number table with blocked randomization, patients were randomly assigned to undergo either free conjunctival autograft transplantation (group A) or limbal- conjunctival autograft transplantation (group B). The main difference between the two groups was inclusion of the limbal stem cells in the conjunctival autograft in group B.

The conjunctival graft was dissected from the superotemporal bulbar conjunctiva. A caliper was used to measure the area of conjunctiva and limbal stem cells were resected with the pterygium. The intended graft area ( $1 \mathrm{~mm}$ larger than the area resected in the pterygium site) was marked in the superotemporal zone with a gentian violet marker pen. Dissection began with the use of conjunctival scissors and forceps from the fornix to approximately $1.5 \mathrm{~mm}$ from the limbus, keeping Tenon's capsule intact. In the case of limbal-conjunctival transplantation (group B), a crescent knife was used to create a superficial circumferential incision in the cornea $0.5 \mathrm{~mm}$ from the limbus, equal in length to the resected limbus. This step was performed before harvesting the conjunctival flap. As soon as the conjunctival part was dissected, limbal dissection was carried forward to include $0.5 \mathrm{~mm}$ of peripheral cornea with the conjunctival graft. At the limbus, the graft was flipped over on to the cornea and the tenon's attachments at the limbus were meticulously dissected. The flap was then excised with approximately $20 \%$ of corneal stroma, extending 0.5 to $1 \mathrm{~mm}$ in to the clear cornea, using a Vannas scissors, taking care to include the limbal tissue. The free graft was placed in the correct orientation onto the scleral bed.

The limbal and conjunctival sides of the graft were sutured to the recipient bed with 4-6 interrupted 10.0 nylon sutures. The area of the graft was left with Tenon's capsule exposed. $0.5 \mathrm{ml}$ Subconjunctival dexamethasone and gentamicin was administered.

After surgery, a pressure patch was used for the first 24 hours, and patients were treated with topical dexamethasone and tobramycin eye drops on a tapered regimen (six times daily, tapering over 2 months) and flurometholone eye ointment (at bedtime for 3weeks). Patients were evaluated and photographed on postoperative days $1,7,14,30$ and 45, then at 6 months.

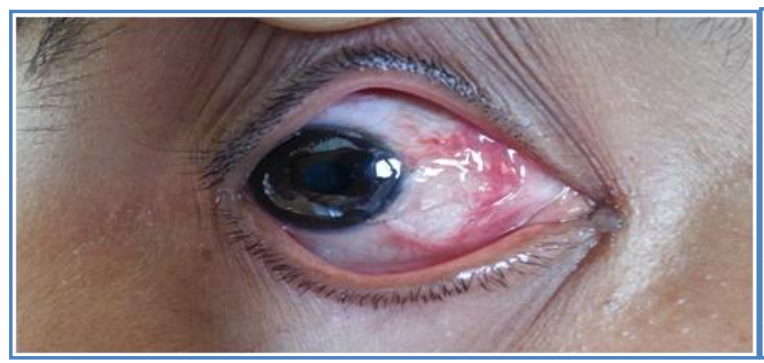

Pic 1: 1' postop day photograph

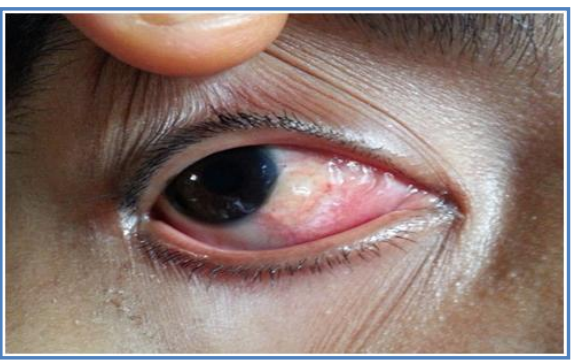

Pic $2: 7^{\text {th }}$ postop day 
Change in astigmatism was documented on $45^{\text {th }}$ postop day.

Recurrence of pterygia was defined as any fibrovascular proliferation encroaching more than $1 \mathrm{~mm}$ onto the cornea from the original pterygium site.

\section{RESULTS:}

\begin{tabular}{|c|c|c|}
\hline VARIABLE & NUMBER & $\%$ \\
\hline SEX & & \\
\hline Male & 68 & 68 \\
\hline Female & 32 & 32 \\
\hline TYPE OF PTERYGIUM & & \\
\hline Grade I & 31 & 31 \\
\hline Grade II & 69 & 69 \\
\hline MEAN AGE & \multicolumn{2}{|c|}{$42.6 \mathrm{yrs}$} \\
\hline
\end{tabular}

Table-1: Demographic Data of the Study $(n=100)$

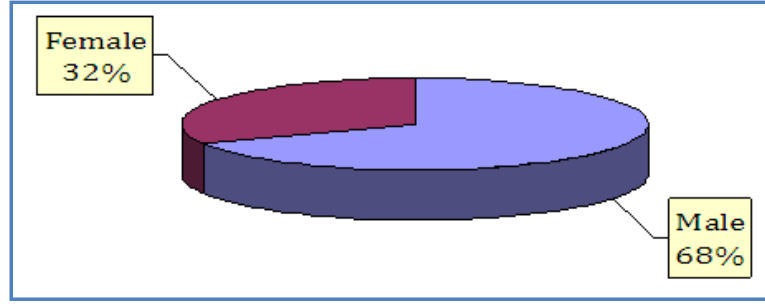

FIG 1: Gender distribution

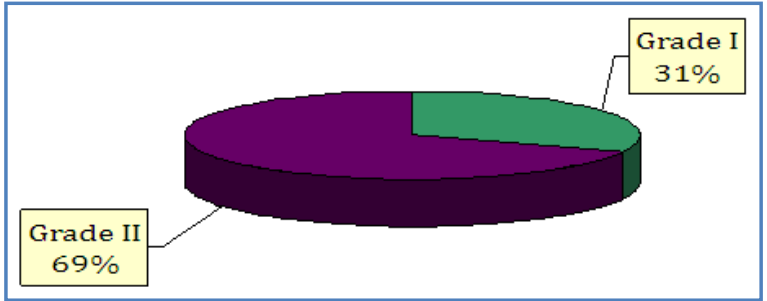

FIG 2: Type of pterygium

1. Astigmatism decreased

\begin{tabular}{|c|c|c|c|}
\hline Amount of astigmatism & WTR & ATR & OBLIQUE \\
\hline $0.5-0.75 \mathrm{D}$ & 6 & 3 & 5 \\
\hline $0.75-1.5 \mathrm{D}$ & 4 & 1 & 3 \\
\hline & 10 & 4 & 8 \\
\hline
\end{tabular}

Table2: Preoperative astigmatism GROUP A

\begin{tabular}{|c|c|c|c|}
\hline Amount of astigmatism & WTR & ATR & OBLIQUE \\
\hline $0.5-0.75 \mathrm{D}$ & 6 & 3 & 5 \\
\hline $0.75-1.5 \mathrm{D}$ & 4 & 2 & 3 \\
\hline & 10 & 5 & 8 \\
\hline
\end{tabular}

Table 3: Preoperative astigmatism GROUP B

\begin{tabular}{|c|c|c|c|}
\hline Amount of astigmatism & WTR & ATR & OBLIQUE \\
\hline $0.5-0.75 \mathrm{D}$ & 4 & 2 & 4 \\
\hline $0.75-1.5 \mathrm{D}$ & 2 & 1 & 1 \\
\hline & 6 & 3 & 5 \\
\hline
\end{tabular}

Table 4: Post operative Astigmatism GROUP A

\begin{tabular}{|c|c|c|c|}
\hline Amount of astigmatism & WTR & ATR & OBLIQUE \\
\hline $0.5-0.75 \mathrm{D}$ & 5 & 2 & 4 \\
\hline $0.75-1.5 \mathrm{D}$ & 2 & 0 & 2 \\
\hline & 7 & 2 & 6 \\
\hline
\end{tabular}

Table 5: Post operative Astigmatism GROUP B

\begin{tabular}{|c|c|c|c|c|}
\hline \multirow{2}{*}{ Astigmatism } & \multicolumn{2}{|c|}{ Group A } & \multicolumn{2}{c|}{ Group B } \\
\cline { 2 - 5 } & Pre op & Post op & Pre op & Post op \\
\hline $0.50-0.75 \mathrm{D}$ & 14 & 10 & 14 & 11 \\
\hline $0.75-1.5 \mathrm{D}$ & 8 & 4 & 9 & 4 \\
\hline
\end{tabular}

Table 6: Comparison of Preoperative and postoperative Astigmatism 
( $\mathrm{p}$ value $=0.909)$

The study showed decrease in astigmatism of all 3 types (WTR, ATR, and Oblique). The decrease in astigmatism was irrespective of whether the patients belonged to group A or B i.e. no significant difference in decrease in astigmatism in the two groups ( $p$ value $=0.909$ ).

2. The cosmetic appearance was generally good.

3. Complications developed were as follows: 4 patients (4\%) developed granuloma formation (2 from Group A and 2 from Group B); 6 patients(6\%) had recurrence ( 3 from group A and 3 from group B).

\begin{tabular}{|l|c|c|}
\hline \multicolumn{1}{|c|}{ Complications } & GROUP A & GROUP B \\
\hline Granuloma formation & 2 & 2 \\
\hline Recurrence & 3 & 3 \\
\hline Table 7: Complication rates in the two groups
\end{tabular}

Table 7: Complication rates in the two groups

DISCUSSION: In our prospective, randomized study, we found that both techniques were effective, with no statistically significant difference ( $p$ value $=0.909$ ) in terms of decrease in astigmatism or recurrence. Our study included 100 patients with pterygia surgically treated with conjunctival and limbal stem cells autograft. The results showed that after a period of follow up of 6 months, $90 \%$ of cases were successfully treated without recurrence of pterygial growth or significant complications. Only $6 \%$ of cases showed recurrence of pterygial growth.

Since the report by Kenyon et al9 of low recurrence associated with conjunctival autografting after pterygium excision, the method became one of the procedures of choice for the surgical management of pterygium. However, prospective, randomized studies of conjunctival autografting after pterygium have shown higher recurrence rates (16\%-39\%) in high-risk populations. ${ }^{33}$

\begin{tabular}{|l|c|c|c|c|}
\hline \multicolumn{1}{|c|}{ Author } & Year & Number of eyes & $\begin{array}{c}\text { AvG Follow-up } \\
\text { (Months) }\end{array}$ & $\begin{array}{c}\text { Recurrence } \\
\text { Rate (\%) }\end{array}$ \\
\hline Kenyon ${ }^{19}$ & 1985 & 57 & 24 & 5.3 \\
\hline Koch $^{34}$ & 1992 & 22 & 8.7 & 9 \\
\hline Guler $^{35}$ & 1994 & 31 & 10 & 13.3 \\
\hline Shimazaki $^{36}$ & 1996 & 27 & 10.9 & 7.4 \\
\hline Rao $^{37}$ & 1998 & 53 & 18.9 & 3.8 \\
\hline Pulte $^{38}$ & 1998 & 70 & 45 & 2.9 \\
\hline Mutlu ${ }^{39}$ & 1999 & 41 & 16 & 14.6 \\
\hline Our study & 2012 & 100 & 6 & 6 \\
\hline \multicolumn{5}{|c|}{ Table-8: Reported recurrence rates following } \\
\hline
\end{tabular}

The recurrence rate reported in our study was $6 \%$ is comparatively les as compared to the other similar studies. The low recurrence rate is encouraging considering the strict definition of recurrence used and the high rate of recurrence in the population. An adequately sized and shaped graft that fits well in the host bed is also important. The graft is dissected as thin as possible avoiding 
button holing. The use of peribulbar anaesthesia is also important as the longer duration of the procedure (Approximately 45 minutes) can be comfortably tackled without compromising the surgical technique. There was reduction in preexisting astigmatism. The cosmetic results were fairly acceptable.

CONCLUSION: Despite the fact that limbal stem cell containing conjunctival autograft and free conjunctival autograft transplantation are time consuming procedures, both are safe and equally effective techniques for the treatment of pterygia. Hence, probably the 'barrier effect' of the autograft is the one responsible for the decrease in recurrence rate rather than the limbal stem cells transferred during the procedure.

\section{BIBLIOGRAPHY:}

1. Kanski JJ, Bowling B.Clinical Ophthalmology: A Systematic approach. $7^{\text {th }}$ ed. Elsevier ; 2011: p163.

2. Rosenthal JW. Chronology of pterygium therapy. Am J Ophthalmol. 1953; 36:1601-1606.

3. Adamis AP, Starck T, Kenyon KR. The management of pterygium. Ophthalmol Clin North Am. 1990;3:611-623.

4. Tan Donald TH, Chee S-P, Dear Keith BG, et al. Effect of pterygium morphology on pterygium recurrence in a controlled trial comparing conjunctival auto grafting with bare sclera excision. Arch Ophthalmol. 1997; 115:1235-1240.

5. Gibson JBG. Brisbane survey of pterygium. Trans Ophthalmol Soc Aust. 1956;16:125-127.

6. Lei G. Surgery for pterygium using a conjunctival pedunculated flap slide. Br J Ophthalmol. 1996;80:33-34.

7. McCoombes JA, Hirst LW, Isbell GP. Sliding conjunctival flap for the treatment of primary pterygium. Ophthalmology. 1994;101:169-173.

8. Desmarres LA. Traite Theorique et Pratique des Maladies des Yeu, 2nd ed. Paris: G. Baillere; 1855:128.

9. Knapp H. A new plastic conjunctival operation. Arch Ophthalmol. 1868; 14:270-272.

10. McReynolds JO. The nature and treatment of pterygia. JAMA. 1902;39: 296-299.

11. Kleis W, Pico G. Thio-TEPA therapy to prevent postoperative pterygium occurrence and neovascularization. Am J Ophthalmol 1973;76:371-3..

12. Tarr KH, Constable IJ. Late complications of pterygium treatment.Br J Ophthalmol 1980;64:496-505.

13. MacKenzie FD, Hirst LW, Kynaston B, Bain C. Recurrence rate and complications after beta irradiation for pterygia. Ophthal mology 1991;98:1776-80; discussion 1781.

14. Rubinfeld RS, Pfister RR, Stein RM, et al. Serious complications of topical mitomycin-C after pterygium surgery. Ophthalmology 1992;99:1647-54.

15. Serrano F. Plastia conjunctival libre en la cirugía del pterigion. Arch Soc Am Oftal Optom. 1977;12:97-102.

16. Kenyon KR, Tseng SCG. Limbal autograft transplantation for ocular surface disorders. Ophthalmology. 1989;96:709-723.

17. Shimazaki J, Yang HY, Tsubota K. Limbal autograft transplantation for recurrent and advanced pterygia. Ophthalmic Surg Lasers. 1996;27: 17-23. 
18. Barraquer JI. The corneo-conjunctival limbus reconstruction before corneal grafting. In: King $\mathrm{JH}$, McTigue J, eds. Proceedings of the First Corneal World Congress. Washington DC: Butterworths; 1965.

19. Kenyon KR, Wagoner MD, Hettinger ME. Conjunctival autograft transplantation for advanced and recurrent pterygium. Ophthalmology 1985;92:1461-70.

20. Prabhasawat P, Barton K, Burkett G, et al. Comparison of conjunctival autografts, amniotic membrane grafts, and primary closure for pterygium excision. Ophthalmology. 1997;104:974985.

21. Jaros PA, DeLuise VP. Pingueculae and pterygia. Surv Ophthalmol 1988;33:41-9.

22. Singh G, Wilson MR, Foster CS. Mitomycin eye drops as treatment for pterygium. Ophthalmology 1988;95:813-21.

23. Starck T, Kenyon KR, Serrano F. Conjunctival autograft for primary and recurrent pterygia: surgical technique and problem management. Cornea 1991;10:196-202.

24. Allan BDS, Short P, Crawford GJ, et al. Pterygium excision with conjunctival autografting: an effective and safe technique. Br J Ophthalmol 1993;77:698-701.

25. Lewallen S. A randomized trial of conjunctival autografting for pterygium in the tropics. Ophthalmology 1989;96:1612-4.

26. Dushku N, Reid TW. Immunohistochemical evidence that human pterygia originate from an invasion of vimentin-expressing altered limbal epithelial basal cells. Curr Eye Res 1994;13:473-81.

27. Tseng SCG. Concept and application of limbal stem cells. Eye 1989;3:141-57.

28. Tseng SCG, Chen JJY, Huang AJW, et al. Classification of conjunctival surgeries for corneal disease based on stem cell concept. Ophthalmol Clin North Am 1990;3:595-610.

29. Kenyon KR, Tseng SCG. Limbal autograft transplantation for ocular surface disorders. Ophthalmology 1989;96:709-22; discussion 722-3.

30. Tsai RJ, Sun TT, Tseng SCG. Comparison of limbal and conjunctival autograft transplantation in corneal surface reconstruction in rabbits. Ophthalmology 1990;97:446-55.

31. Koch JM, Mellin KB, Waubke TN. [The pterygium, autologous conjunctiva-limbus transplantation as treatment]. Ophthalmology 1992;89:143-6.

32. Guler M, Sobaci G, Ilker S, et al. Limbal-conjunctival autograft transplantation in cases with recurrent pterygium. Acta Ophthalmol (Copenh) 1994;72:721-6.

33. Young AL, Leung GY, Wong AK, Cheng LL, Lam DS. A randomised trial comparing 0.02\% mitomycin $\mathrm{C}$ and limbal conjunctival autograft after excision of primary pterygium. $\mathrm{Br}$ JOphthalmol.2004;88:995-7.

34. Koch JM, Mellin JB, Wauble TN. The pterygium- Autologous conjunctiva-limbus transplantation as treatment. Ophthalmology 1992;89:143-6.

35. Guler M, Sobaci G, Liker S, Ozturk F, Muthi FM, Yildirim E. Conjunctival autograft transplantation in cases with recurrent pterygium. Acta Ophthalmol 1994;72:721-6.

36. Shimazaki J, Yang HY, Tsubota K. Limbal autograft transplantation for recurrent and advanced pterygia. Ophthalmic Surg Lasers 1996;27:917-23.

37. Rao SK, Lekha T, Mukesh BN, Sitalakshmi G, Padmanabhan P. Conjunctival-limbal autograft for primary and recurrent pterygia: Technique and results. Indian J Ophthalmol 1998;46:203-9. 
38. Pulte $\mathrm{P}$, Heiligenhaus A, Koch J. Long term results of autologous conjunctiva-limbus transplantation in pterygium. Klin Monatsbl Augenheilkd 1998;213:9-14.

39. Mutlu FM, Sobaci G,Tatar T, Yildirim E. A comparative study of recurrent pterygium surgery: Limbal conjunctival autograft transplantation versus mitomycin-C with conjunctival flap. Ophthalmology 1999;106:817-21.

\section{AUTHORS: \\ 1. K. Satish \\ 2. D.N. Prakash \\ 3. Meghana Tanwar \\ 4. Madhumita Gopal \\ 5. Savita Patil \\ 6. Ambika A Acharya \\ 7. Amar Kulkarni \\ 8. Mohan Setlur}

\section{PARTI CULARS OF CONTRIBUTORS:}

1. Associate Professor, Department of Ophthalmology, K.R. Hospital, Mysore Medical College and Res earch Institute, Mysore.

2. Assistant Professor, Department of Ophthalmology, K.R. Hospital, Mysore Medical College and Res earch Institute, Mysore.

3. Resident, Department of Ophthalmology, K.R. Hospital, Mysore Medical College and Research Institute, Mysore.

4. Resident, Department of Ophthalmology, K.R. Hospital, Mysore Medical College and Research Institute, Mysore.
5. Resident, Department of Ophthalmology, K.R. Hospital, Mysore Medical College and Research Institute, Mysore.

6. Resident, Department of Ophthalmology, K.R. Hospital, Mysore Medical College and Research Institute, Mysore.

7. Resident, Department of Ophthalmology, K.R. Hospital, Mysore Medical College and Research Institute, Mysore.

8. Resident, Department of Ophthalmology, K.R. Hospital, Mysore Medical College and Research Institute, Mysore.

\section{NAME ADDRESS EMAIL ID OF THE CORRESPONDING AUTHOR:}

Dr. K. Satish, Department of Ophthalmology, MMC \& RI, K.R. Hospital, Irwin Road, Mysore - 570001.

Email -drsatishkeshav@gmail.com

Date of Submission: 07/10/2013.

Date of Peer Review: 08/10/2013.

Date of Acceptance: 26/10/2013.

Date of Publishing: 06/11/2013 